\title{
Evolution of Hutti-Maski greenstone belt of the Eastern Dharwar Craton: Evidence for metamorphic and hydrothermal phases from the Hira-Buddini deposit, Raichur district, Karnataka, India
}

\author{
Kunda V BADHE* and H S PANDALai \\ Department of Earth Sciences, Indian Institute of Technology Bombay, Powai, Mumbai 400076, India. \\ *Corresponding author.e-mail: kundabadhe@gmail.com
}

MS received 23 October 2017; revised 23 January 2018; accepted 28 January 2018;

published online 18 August 2018

The Hira-Buddini gold deposit is located along the steeply dipping ENE trending sheared contact of felsic and mafic rocks of strike length of about $600 \mathrm{~m}$ with mylonitic foliation parallel to the S1 schistosity in amphibolites. Second-generation open folds with axial planes (S2) marked by fractures that are often filled by later calcite veins are observed in surface and underground exposures. Garnetiferous amphibolites occur in patches on the footwall side of the shear in the western part of the deposit. This rock shows garnet porphyroblasts, coarse second-generation hornblende and large grains of biotite that grow over an early S1 fabric which is made up of early hornblende, plagioclase, ilmenite and retrograde firstgeneration chlorite. Second-generation hornblende and biotite grains make high angles to S1 schistosity and are sub-parallel to S2. Late hydrothermal alteration is marked by an albite-epidote-chlorite-zoisite assemblage. Geothermometric estimates based on garnet-biotite, and garnet-hornblende pairs, as well as $\mathrm{Ti}$ in biotite, show that temperatures during D2 deformation that led to the growth of the porphyroblasts were $530 \pm 20^{\circ} \mathrm{C}$. The fabric and mineralogy of the rock indicate that porphyroblastic growth of garnet, hornblende and biotite was preceded and succeeded by stages of hydrothermal alteration. Primary gold mineralization is inferred to be associated with the early stage of hydrothermal ingress.

Keywords. Hutti-Maski greenstone belt; Hira-Buddini gold deposit; geothermometry.

\section{Introduction}

The Hutti-Maski greenstone belt is an important auriferous greenstone belt of the Eastern Dharwar Craton (EDC) of Karnataka in southern India with several gold prospects and the Hutti deposit which, at present, is the only major gold-producing deposit of India. Petrogenetic and tectonic models, geochemistry of metamorphism and oremineralization in the Hutti-Maski greenstone belt have been studied by several workers (Anantha Iyer and Vasudev 1979; Giritharan and Rajamani 1998; Kolb et al. 2005; Rogers et al. 2007; Mishra and Pal 2008; Manikyamba et al. 2009). It is generally accepted that the volcano-sedimentary belt may be interpreted in terms of an arc-setting in

Supplementary material pertaining to this article is available on the Journal of Earth System Science website (http://www. ias.ac.in/Journals/Journal_of_Earth_System_Science). 
which auriferous fluids of deep crustal or mantle origin circulated through high-angle shear zones to deposit gold in an environment that was conducive to rapid de-gassing of fluid and change in $\mathrm{P}$ and $\mathrm{T}$ (Nevin et al. 2010). Previous studies within the Hutti greenstone belt have indicated that the gold mineralization may have occurred in two stages. (Hazarika et al. 2015, 2016, 2017, Rogers et al. (2013), Mishra and Pal (2008), Krienitz et al. (2008), Kolb et al. (2005), Saha and Venkatesh (2002), Pal and Mishra (2002), Naganna (1987), Roy (1991), Raju (1978), and Raju and Sharma (1991) have also recognized that the principal stage of gold mineralization was followed by the second stage of mineralization which might have led to concentration of gold.

Roy (1979, 1991), Vasudev and Chadwick (2008) and Nevin et al. (2010) have identified four phases of deformation (that includes the last phase of brittle deformation) in the Hutti-Maski greenstone belt. These workers have suggested that the major phase of mineralization is associated with shearing that occurred in the later stages of the first phase of deformation. Early deformation (D1) and prograde metamorphism (M1) is followed by retrogression (M2) along with shearing and hydrothermal mineralization in the late D1 phase. In this model, the D2 stage of deformation did not produce significant metamorphism or neo-mineralization but may have led to remobilization of gold and sulfides into structurally favorable zones. The D3 and D4 phases are relatively minor phases of deformation. Pandalai et al. (2003, 2004) suggested that the main phase of gold mineralization occurred during the late D1 phase between $360^{\circ}$ and $240^{\circ} \mathrm{C}$ at pressures between 3.6 and 1.6 kbars with fluctuations in $\mathrm{P}$ and $\mathrm{T}$ resulting from a fault-valve mechanism controlling fluid pressure in the Hutti shear system.

On the other hand, the model proposed by Kolb et al. (2005) and Rogers et al. (2013) envisages five distinct phases of deformation with early prograde metamorphism (M1) at $660 \pm 40^{\circ} \mathrm{C}$ and $4 \pm 1$ kbars pressure followed by two distinct stages of retrograde metamorphism. The first phase of retrograde metamorphism (M2) is estimated to have occurred at $560 \pm 60^{\circ} \mathrm{C}$ and $2 \pm 1$ kbars pressure that coincided with their D2 stage of deformation (and 1st phase of gold mineralization), followed by the second stage of retrogression (M3) at $300-350^{\circ} \mathrm{C}$ and 2 kbars pressure that coincided with their D3 stage of deformation and the second stage of gold mineralization (Rogers et al. 2013). Mishra and Pal (2008) have also suggested prograde metamorphism (M1) at $600-680^{\circ} \mathrm{C}$ at $5-6 \mathrm{kbars}$ pressure, while $\mathrm{Pal}$ and Mishra (2002) gave estimates of $635-685^{\circ} \mathrm{C}$ at 5 kbars pressure for the same event. Mishra and Pal (2008) suggest that the early phase of gold and sulfide mineralization occurred along with D2 phase of deformation (as identified by Kolb et al. 2005) at $400-500^{\circ} \mathrm{C}$ at a pressure around 2 kbars (which is the M2 phase of Kolb et al. 2005). The second phase of mineralization is inferred by them to have occurred between 280 and $320^{\circ} \mathrm{C}$ at 1 to 1.7 kbars consistent with the observation of $\mathrm{Pal}$ and Mishra (2002). The second phase of mineralization is inferred to have occurred during the D3 phase of deformation (and M3 phase of metamorphism) of Kolb et al. (2005).

In the present study, garnetiferous amphibolites around the Hira-Buddini deposit are studied and the textural relationships are interpreted in terms of metamorphism and alteration with the purpose of contributing to the understanding of the geological processes involved in the evolution of the Hutti greenstone belt and the gold mineralization in it.

\section{Geological setting}

The Hutti-Maski greenstone belt is a $74 \mathrm{~km}$ long $\mathrm{N}-\mathrm{S}$ trending volcano-sedimentary belt with metamorphosed mafic volcanic rocks being the predominant lithology (figure 1). Towards the northern part, the belt takes an eastward bend and stretches eastwards for about $30 \mathrm{~km}$. The Hutti gold deposit is located in the north of the belt towards the western side. The Hira-Buddini gold deposit is located about $23 \mathrm{~km}$ east of Hutti Gold Mine. The Hutti-Maski greenstone belt has been mapped on a 1:50,000 scale by the Geological Survey of India and regional studies on the geology and structure of this belt are available in Roy $(1979,1991)$ and Vasudev and Chadwick (2008).

The Hutti-Maski greenstone belt consists of a succession of rocks that overlie the Peninsular Gneisses and were deposited in a supra-crustal setting that developed after the cratonization of the Archean proto-continent (Jayananda et al. 2013). Basal conglomerates are not observed anywhere and the succession consists predominantly of pillowed lavas and massive lava flows with smaller intercalations of clastic rocks. Sill-like felsic volcanic rocks are observed at many locations in the greenstone belt. These felsic volcanic rocks are generally less than a metre to a few metres 


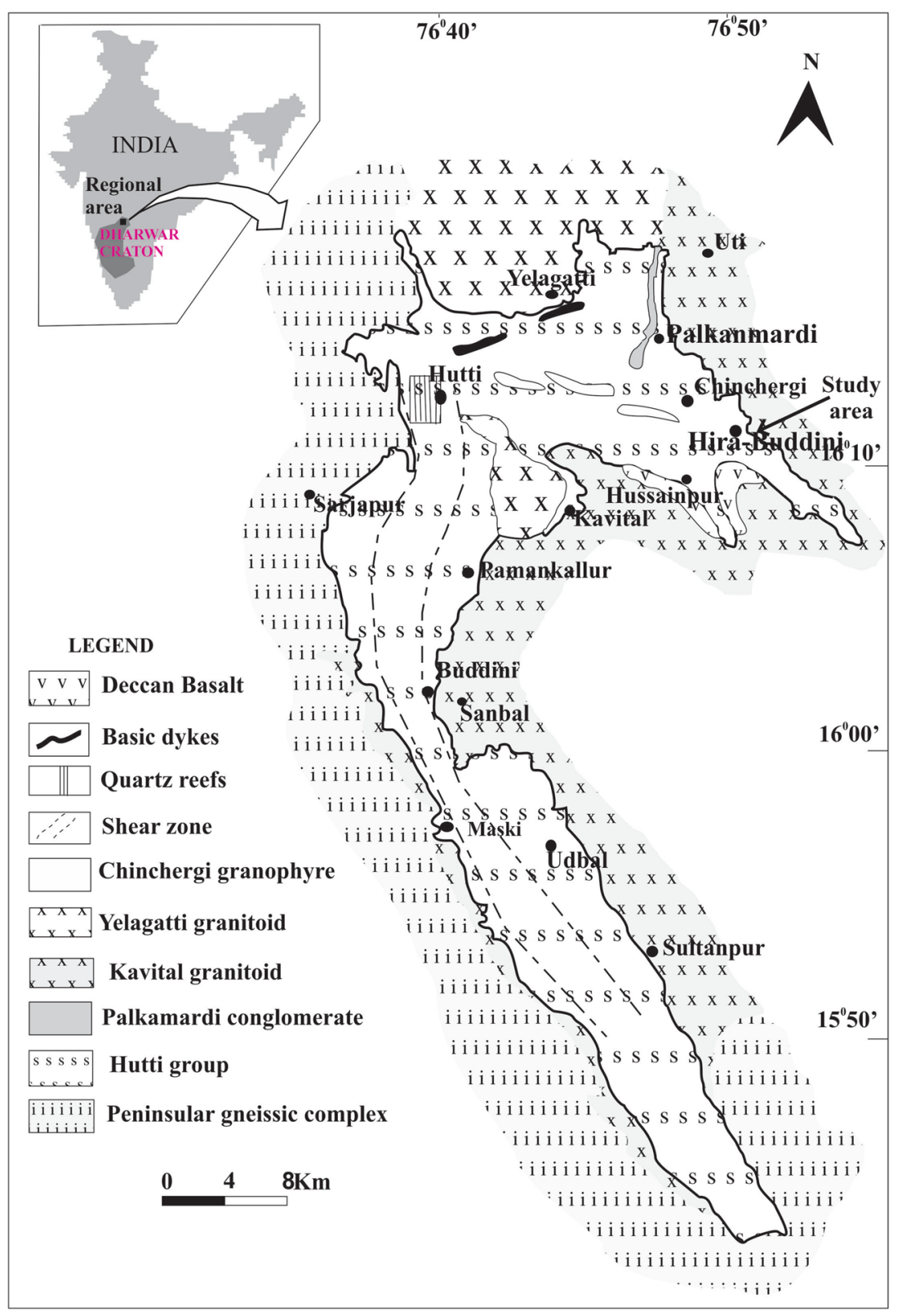

Figure 1. Geological map of Hutti-Maski schist belt (modified after Srikantia 1995).

wide and extend for hundreds of metres. The felsic rocks are observed in the underground workings in the Hutti mine, at Chinchergi, Gajalgatta, HiraBuddini and Wandali (Manikyamba et al. 2009). The felsic rocks that occur close to Chinchergi are intrusive rocks with greasy translucent porphyritic quartz in a matrix of plagioclase feldspar and have been described by Srikantia (1995) as quartz-granophyres, petrographically they resemble dacites. These rocks are identified as adakite based on their geochemistry (Manikyamba et al. 2009; Mallik 2011; Nevin 2012).

The Hutti-Maski schist belt is surrounded by granites and gneisses. The gneisses are mainly exposed to the western side of the schist belt. The granites are mainly exposed to the north, the south-east and the east of the schist belt and are intrusive into it. Two types of granitoids are observed; one is a grey-granitoid (the Kavital granitoid) in the south-east and the other is a pinkgranitoid that is typified by the Yelgatti granitoid to the north of the schist belt (Srikantia 1995).

The occurrence of the Palkanmardi conglomerate with ellipsoidal to sub-ellipsoidal and rounded fragments of Peninsular gneisses and more angular fragments of amphibolites embedded in a matrix of a volcanic material and sediments (Roy 1979; Roy and Biswas 1982) within the stratigraphic 


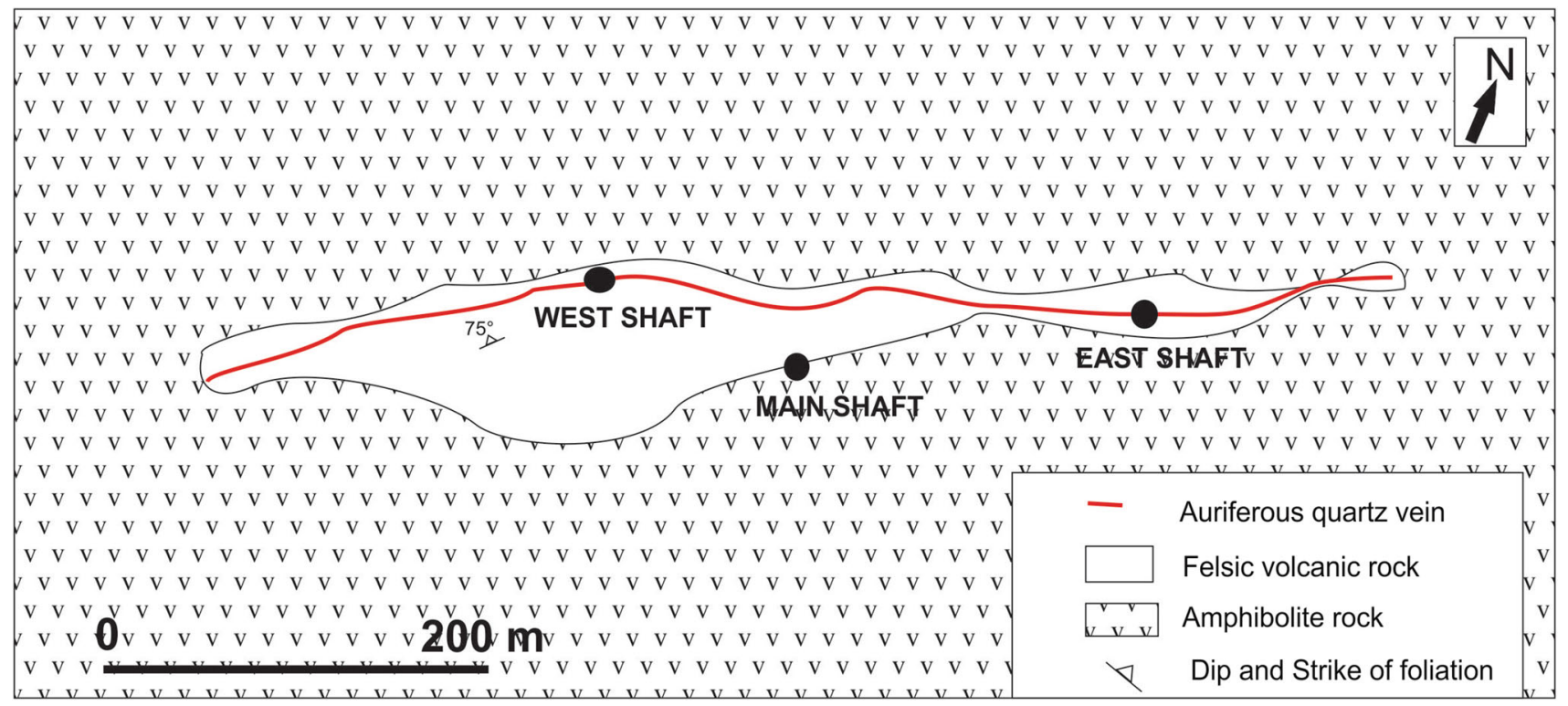

Figure 2. Geological map of the Hira-Buddini gold deposit (modified after Sangurmath 2003; Mallik 2011).

sequence of the Hutti rocks indicates that there may have been upliftment and partial inversion of the basin before the basin was completely inverted. $\mathrm{U}-\mathrm{Pb}$-SHRIMP dates from zircon separated from the granodioritic clasts give an age of $2576 \pm 12 \mathrm{Ma}$ (Vasudev et al. 2000).

The Hira-Buddini gold deposit is located on the eastern limb of the major Hutti F2 fold (figure 1) and close to the axis of the eastern synform of the Hutti-Maski greenstone belt (Roy 1979; Curtis and Radhakrishna 1995; Srikantia 1995; Sangurmath 2003). The area is dominated by amphibolite with a linear, sill-like body of felsic metavolcanic rock (figure 2). The metabasalts show foliation (S1) that runs parallel to the contact with the felsic volcanic rocks and has a dominant orientation of $\mathrm{N} 70^{\circ} \mathrm{E}$ with a dip of about $80-85^{\circ}$ due $\mathrm{N} 20^{\circ} \mathrm{W}$. S1 foliation shows gentle open folds with subvertical axial planes that trend $\mathrm{N} 5-10^{\circ} \mathrm{W}$. The axis of these folds plunges about $80^{\circ}$ due $\mathrm{N} 5-10^{\circ} \mathrm{W}$ (Mallik 2011). These gentle open folds are F2 folds developed on the limbs of the major F2 folds in the Hira-Buddini area. Numerous thin calcite veins occur in fractures parallel to the axial planes of the F2 folds. The auriferous lode is almost parallel $\left(\mathrm{N} 75^{\circ} \mathrm{W}\right)$ to the sheared contact of the amphibolite and felsic metavolcanic rock (figure 2). The strike length of the lode is about $600 \mathrm{~m}$ and the thickness varies from 1 to $3.5 \mathrm{~m}$. Gold mineralization is observed with thin quartz veins that occur along the sheared contact of felsic volcanic rock and metabasalt along with minor sulfides consisting of pyrite, pyrrhotite and chalcopyrite. The lode strikes ENE-WSW with steep dip $\left(>70^{\circ}\right)$ due north (Sangurmath 2003, 2005). Sub-vertical foliation that dips about $85^{\circ}$ due $\mathrm{N} 5^{\circ} \mathrm{W}$ that strikes more or less perpendicular to the strike of the lode is observed in the Hira-Buddini underground exposures. The underground exposures at HiraBuddini also show numerous sub-horizontal veins of quartz and calcite. The sub-horizontal veins that are observed have been interpreted by Mishra and Pal (2008) as extensional veins developed perpendicular to the subvertical shear system that hosts the gold mineralization. The rock types observed in the underground openings of the Hira-Buddini mine include sheared metabasalts, felsic volcanic rocks and veins of quartz, calcite and tourmaline (Sahoo et al. 2016).

Garnet-bearing rocks are observed in the HuttiMaski greenstone belt at few locations. In the course of the present study, they have been observed at Uti and at Hira-Buddini. At HiraBuddini, garnet bearing amphibolites are obtained in the 4th level of the underground workings, close to ore bearing amphibolites.

\section{Analytical technique}

In the present work, Electron Probe Micro Analysis (EPMA) studies were carried out on garnetiferous schist of the Hira-Buddini deposit for detailed mineralogical characterization of the metamorphic and 
alteration assemblage in the rock. The variation in the chemistry of the metamorphic minerals and their alteration products and their classification helps correlation of alteration with mineralization stages. Points close to the core and a few points towards the rims of garnet, hornblende and biotite grains were analyzed. For the purpose of garnethornblende and garnet-biotite geothermometry, the analyses of the core of garnet-hornblende and garnet-biotite pairs were used. In addition, Ti values in the core of biotite grains of the samples of garnetiferous amphibolite were also used for Ti-biotite geothermometry.

The analysis was carried out on CAMECA SXFive with 5 wavelength spectrometers at EPMA laboratory, Department of Earth Sciences, Indian Institute of Technology Bombay. The analytical conditions included accelerating voltage of $20 \mathrm{keV}$ and beam current of $200 \mathrm{nA}$ with a beam diameter of $1 \mu \mathrm{m}$. The standards used for the analysis of major oxides were natural silicates.

\section{Results: Petrographic observations}

Altered amphibolites make up most of the underground exposures of the Hira-Buddini mine. Sometimes the rock shows amphibole-rich bands with other bands rich in plagioclase and quartz. Biotite, calcite and quartz are observed in increasing proportion close to the sheared contact of the metabasalt with the felsic volcanic rock. Numerous small ilmenite grains (as identified by reflected light microscopy) are observed in the amphibole rich bands. The sheared felsic volcanic rocks are composed of quartz, plagioclase, orthoclase and sericite with minor chlorite. Most of the feldspar grains show alteration to sericite. Quartz grains are often stretched and form ribbon-like grains. Some other quartz grains form porphyroclasts that underwent recrystallization. Tourmaline-rich schistose rocks rich in amphiboles, chlorite, epidote and quartz are also observed in patches in the underground openings. Tourmaline often constitutes $5-10 \%$ of the rock and sometimes aggregate to form bands up to $1 \mathrm{~mm}$ thick. This rock is an amphibolite that has been hydrothermally altered giving rise to a tourmaline-rich rock.

The amphibolites at Hira-Buddini clearly show two sets of hornblende grains and two sets of chlorite grains and some amphibolites are garnetiferous (figure 3). Early hornblende (Hbl-I) and plagioclase grains are aligned and define the primary fabric (S1) of the rock. The numerous bands of opaques are aligned parallel to S1 defined by hornblende and plagioclase. Early chlorite grains are also seen aligned parallel to S1 (figure 3c). This early chlorite is termed as chlorite I (Chl-I). The parallelism of the S1 schistosity defined by the early hornblende, plagioclase and the ilmenite bands indicate that they are the products of the first phase of metamorphism. The $\mathrm{S} 1$ foliation is parallel to the mylonitic foliation that has developed along the ENE-WSW trending shear zone at the contact of the felsic and mafic volcanic rocks. Gold mineralization occurs in the narrow zone of shearing along the contact of the felsic and mafic volcanic rocks.

Previous work on alteration of metabasalts of the Hutti-Maski greenstone belt have also clearly identified an early phase of hydrothermal alteration in Hutti and Hira-Buddini in which hornblende is altered to biotite in the regions proximal to quartz reefs (Roy 1979; Naganna 1987; Pal and Mishra 2002; Pandalai et al. 2003, 2004; Kolb et al. 2005; Nevin et al. 2010; Rogers et al. 2013; Hazarika et al. 2016). In the present study, early biotite grains (BtI) are observed in metabasalts close to the shear zone, parallel to $\mathrm{S} 1$ foliation. In the garnetiferous schists the early biotite is not observed.

The second sets of hornblende grains (Hbl-II) are nearly perpendicularly oriented to the early schistosity (figure 3a). These grains are large prismatic grains that look relatively fresh. Biotite flakes (BtII) are also oriented parallel to the second set of hornblende. Both the second set of hornblende (Hbl-II) and the biotite (Bt-II) cut across the early schistosity and overgrow the earlier hornblende (Hbl-I), plagioclase (Plag-I) and chlorite (Chl-I). The opaque grains which have been confirmed to be ilmenite grains are included in the later-formed hornblende and biotite grains.

Garnetiferous amphibolites that have been altered to garnetiferous schist are seen in the underground exposures of the Hira-Buddini mine and samples were taken from the fourth level to the west of the Main shaft. Microscopic observation shows that the rock is made up of biotite, chlorite, garnet, amphiboles, plagioclase, epidote, albite, quartz and zoisite besides numerous bands of opaques. The second set of large hornblende grains are seen juxtaposed with the garnet and the two minerals along with the biotite appear to have grown synchronously (figure $3 \mathrm{a}$ and b). Garnet occurs as large porphyroblasts (150-200 $\mu \mathrm{m}$ 

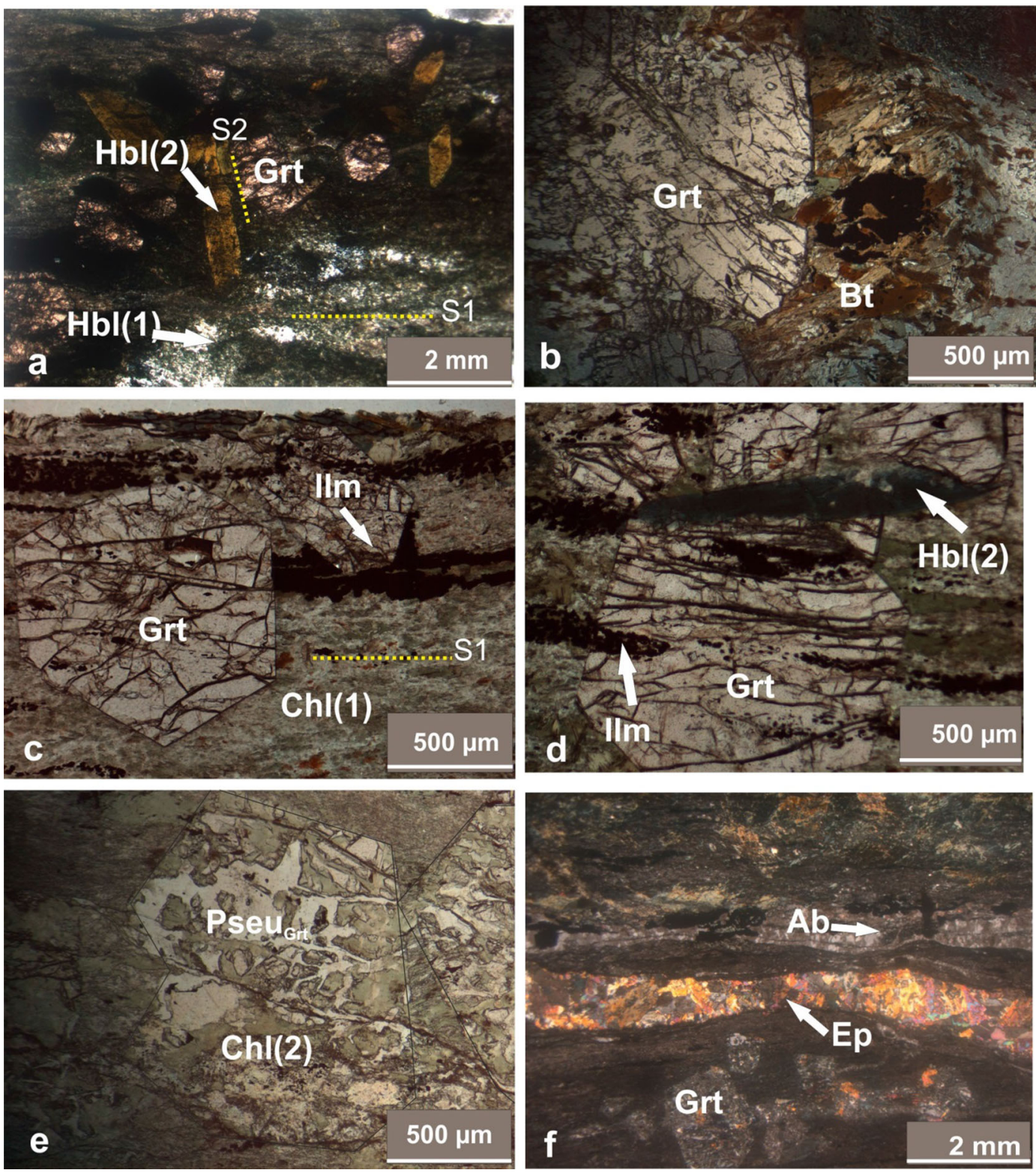

Figure 3. Photomicrographs of garnetiferous biotite schist from Hira-Buddini underground mine (all photomicrographs are in plane-polarized light except ( $\mathbf{d}$ and $\mathbf{f}$ which are partially crossed). (a) garnet porphyroblast with biotite and hornblende grains; (b) large second-generation hornblende grains parallel to S2 with garnet and small first generation hornblende grains of the matrix parallel to S1; (c) garnet porphyroblast that overgrows the early S1 schistosity defined by ilmenite bands and chlorite I; (d) garnet porphyroblasts overgrown over thin bands of ilmenite parallel to S1 schistosity; (e) pseudomorph of garnet composed of chlorite epidote and albite; and (f) epidote and albite veins in altered garnetiferous schist.

in size) that are developed over an earlier fabric marked by early hornblende-plagioclase-ilmenite assemblage (figure $3 \mathrm{c}$ and $\mathrm{d}$ ). Ilmenite bands are seen to extend within the garnet grains. The garnet porphyroblasts truncate the early fabric sharply. The hornblende (Hbl-II) and biotite (Bt-II) grains make a high angle (nearly 80$90^{\circ}$ ) with the S1 schistosity and are sub-parallel with the trends of the axial planes of F2 folds marked by numerous and often, calcite-filled, fractures.
Excellent pseudomorphs of garnet are observed (figure 3e). In some sections, there are numerous vein-like bodies containing albite, epidote, chlorite and zoisite with other opaques identified as pyrrhotite. In the close vicinity of these grains, garnets are seen completely altered to albite, epidote and chlorite (figure 3f). The chlorites associated with these vein-like bodies are termed chlorite II (Chl-II). From this rock, it is clear that the early fabric of hornblende (Hbl-I) and plagioclase (PlagI) along with the bands of ilmenite have been 
Table 1. Description of the garnetiferous amphibolite collected from Hira-Buddini mine (4th level).

\begin{tabular}{lll}
\hline Sample no. & \multicolumn{1}{c}{ Location } & \multicolumn{1}{c}{ Description } \\
\hline HBN-4 & 4th level west drive Hira-Buddini & Hbl(1)-Chl(1)-Ilm \\
& & Grt-Hbl(2), Bt, Ep, Chl-Zoi, Ab \\
HRM-4 & 4th level west drive Hira-Buddini & Hbl(1)-Chl(1)-Ilm \\
& & Grt-Hbl(2), Ep, Chl-Zoi, Ab \\
\hline
\end{tabular}

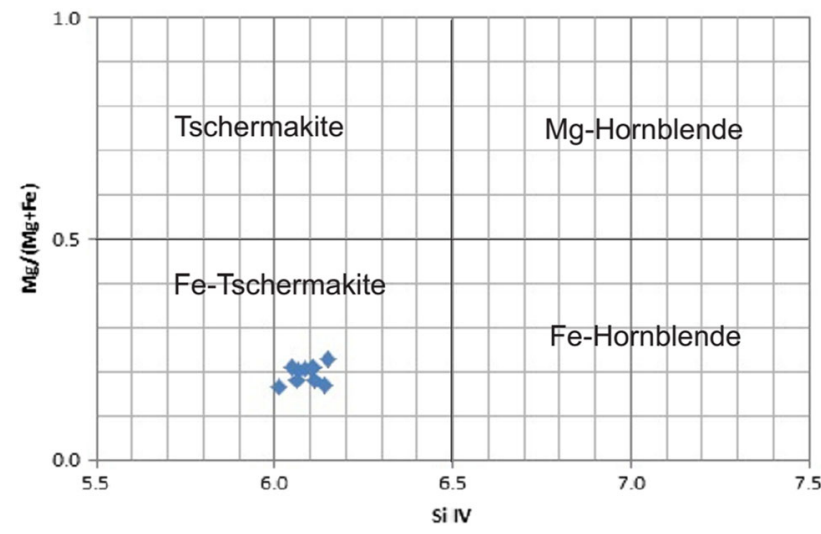

Figure 4. Classification of amphibole from Hira-Buddini underground mine (classification scheme after Leake et al. 1997).

first chloritized by early chlorite (Chl-I) and then overprinted by the second generation of hornblende (Hbl-II) along with new biotite (Bt-II) and garnet. The veins of albite-epidote-chlorite II-quartz and zoisite are formed after the growth of garnets and have completely altered the garnets in the close vicinity of these veins (figure $3 \mathrm{f}$ ).

\section{Mineral chemistry of garnetiferous amphibolites and geothermometry}

In the present study, the garnet-Hbl-II and garnetBt-II assemblage from Hira-Buddini have been studied to obtain estimates of the temperature of the second metamorphic event. Two samples as given in table 1 were studied. The amphiboles and biotite were classified using the Leake et al. (1997) and Deer et al. (1992). The method of Droop (1987) was used for the $\mathrm{Fe}^{2+}$ calculation for garnet and biotite. The method of Droop (1987) as adopted in Schumacher (1997) was used for computation of $\mathrm{Fe}^{2+}$ in amphiboles. The EPMA results of garnet and co-existing hornblende and biotite are given in the supplementary file.

The composition of the amphibole is plotted in figure 4 in the $\mathrm{Si}^{\mathrm{IV}}$ vs. $\mathrm{Mg} / \mathrm{Mg}^{+} \mathrm{Fe}^{2+}$ diagram

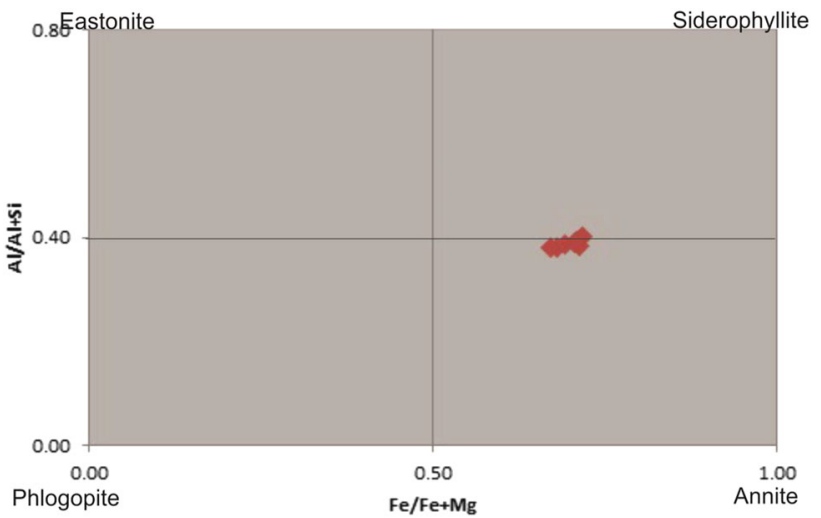

Figure 5. Classification of biotite from Hira-Buddini underground mine (classification scheme after Deer et al. 1992).

of Leake et al. (1997). The amphiboles from Hira-Buddini mine plot in the Fe-tschermakite field and hence are compositionally different from the hornblende in the metabasalts of the Hutti mine which are richer in $\mathrm{Mg}$ and $\mathrm{Si}^{\mathrm{IV}}$. Figure 5 shows the plot of the composition of biotite in the $\mathrm{Fe} / \mathrm{Fe}+\mathrm{Mg}$ vs. $\mathrm{Al} / \mathrm{Al}+\mathrm{Si}$ diagram. The plot shows that these biotite grains plot in the annite field (comparatively, biotites in the alteration zone of Hutti are more $\mathrm{Mg}$ rich).

The garnets were analyzed from core to rim (figure 6). There is a steady zonation in garnet composition with $\mathrm{MnO}$ depleted at the core and $\mathrm{Fe}$ increasing towards the core. $\mathrm{MgO}$ content does not show significant variation from core to rim of the garnet. The zoning of garnet shows a fairly steep increase in $\mathrm{Mn}$ content from the rim inwards. This increase flattens out and in the core region, there is sudden fall in Mn content. Concomitantly there is a slight decrease in Fe from the rim inwards, followed by an increase in the central part of the grain. $\mathrm{MgO}$ also shows a somewhat similar trend as Fe although the differences from rim to core are smaller. The composition of the garnet is plotted in figure 6(c) and reveals that the garnet is an almandine-rich garnet. In the present case, it is clear that there is an overgrowth of garnet on a core grain. The overgrown (outer) garnet shows typical Mn, Fe, Mg 


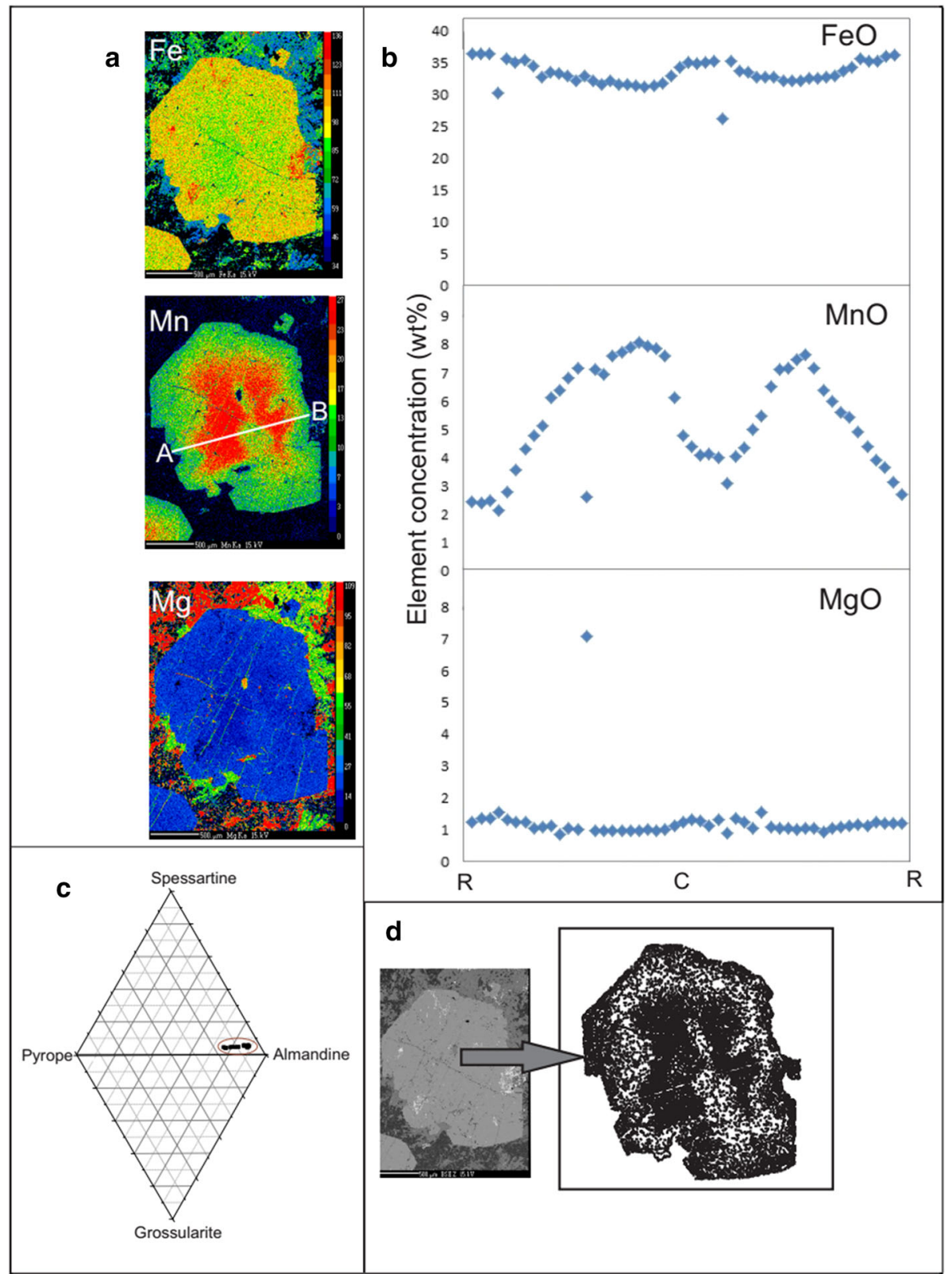

Figure 6. Garnet compositional diagram: (a) X-ray map of garnet in garnetiferous amphibolite from the Hira-Buddini underground mine showing zoning as depicted using false color; (b) elemental concentration in weight \% FeO, MnO and $\mathrm{MgO}$ along the profile line A-B shown in (a) (C: core, R: rim); (c) garnet classification; and (d) back-scatter electron image of garnet arrow direction illustrating its elemental zoning.

zonation. It is interpreted that this zonation is an account of diffusion during alteration as the values change rapidly inwards from the rim to form a more uniform inner zone before changing again at the core.

In the present study, it is interpreted that the second hornblende present in the sample, i.e., the hornblende that cross-cuts the early fabric of the early hornblende and chlorite is a hornblende that was formed in equilibrium with the inner garnet. In consonance with this interpretation, EPMA analysis of hornblende grains with the inner garnet is taken for determination of temperature.

\subsection{Hornblende garnet geothermometry}

The temperature of growth of garnet and hornblende in equilibrium with each other during the second phase of metamorphism, subsequent to the first phase of metamorphism and retrogression with the development of early chlorite, is estimated. Hornblende-garnet geothermometers proposed by 
Table 2. Summary of garnet-hornblende geothermometry of garnetiferous amphibolite.

\begin{tabular}{|c|c|c|c|c|c|c|c|c|}
\hline \multicolumn{9}{|c|}{ Garnet-hornblende geothermometry } \\
\hline \multirow[b]{2}{*}{$\begin{array}{c}\text { Analysis } \\
\text { pts }\end{array}$} & \multicolumn{2}{|c|}{ Garnet } & \multicolumn{2}{|c|}{ Hornblende } & \multirow[b]{2}{*}{$K_{D}$} & \multirow[b]{2}{*}{$\ln K_{D}$} & \multirow[b]{2}{*}{$T(\mathrm{~K})$} & \multirow[b]{2}{*}{$\mathrm{T}\left({ }^{\circ} \mathrm{C}\right)$} \\
\hline & $\mathrm{Fe}^{+2} / \mathrm{Mg}$ & $\mathrm{X}_{\mathrm{Ca}}$ & $\begin{array}{c}\text { Analysis } \\
\text { points }\end{array}$ & $\mathrm{Fe}^{+2} / \mathrm{Mg}$ & & & & \\
\hline Core-45 & 19.22 & 0.09 & 48 & 4.47 & 4.30 & 1.46 & 818.4 & 545 \\
\hline Core-45 & 19.22 & 0.09 & 53 & 3.82 & 5.03 & 1.62 & 786.3 & 513 \\
\hline Core-36 & 17.45 & 0.09 & 41 & 3.75 & 4.66 & 1.54 & 803.7 & 531 \\
\hline Core-17 & 17.45 & 0.09 & 20 & 3.82 & 4.57 & 1.52 & 807.8 & 535 \\
\hline
\end{tabular}

Graham and Powell (1984), and Ravna (2000) have been widely used in the literature. Hornblendegarnet geothermometry based on the geothermometer of Graham and Powell (1984) is used here as it was found to give more consistent results on temperature for the studied samples. The geothermometer proposed by Graham and Powell (1984) is a $\mathrm{Fe}-\mathrm{Mg}$ exchange geothermometer based on the reaction.

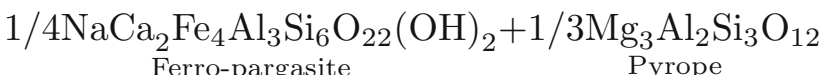

$$
\begin{aligned}
& =1 / 4 \mathrm{NaCa}_{2} \mathrm{Mg}_{4} \mathrm{~A}_{3} \mathrm{Si}_{6} \mathrm{O}_{22}(\mathrm{OH})_{2}+1 / 3 \mathrm{Fe}_{3} \mathrm{Al}_{2} \mathrm{Si}_{12} \text {. }
\end{aligned}
$$

The above geothermometer of Graham and Powell (1984) has been calibrated by them against the garnet-clinopyroxene thermometry of Ellis and Green (1979). The temperature is given by the equation below

$$
T(\mathrm{~K})=\frac{2880+3280 \mathrm{Xca}, \mathrm{g}}{\ln K_{\mathrm{D}}+2.426}
$$

where $\mathrm{K}_{D}$ is given by $\left(\mathrm{X}_{\mathrm{Fe}, \mathrm{g}} / \mathrm{X}_{\mathrm{Mg}, \mathrm{g}}\right) /\left(\mathrm{X}_{\mathrm{Fe}, \mathrm{Hbl}} /\right.$ $\left.\mathrm{X}_{\mathrm{Mg}, \mathrm{Hbl}}\right)$.

The results of the EPMA analyses are given in the supplementary file along with the calculation of $\mathrm{X}_{\mathrm{Fe}, \mathrm{Grt}}, \mathrm{X}_{\mathrm{Mg}, \mathrm{Grt}}, \mathrm{X}_{\mathrm{Ca}, \mathrm{Grt}}, \mathrm{X}_{\mathrm{Fe}, \mathrm{Hbl}}$ and $\mathrm{X}_{\mathrm{Mg}, \mathrm{Hbl}}$. The temperature computed from hornblende (HblII) analyses paired with analysis of slightly inner spots of garnet are computed the results are presented in table 2 . The temperature varies from 513 to $545^{\circ} \mathrm{C}$ with a mean value of $531^{\circ} \mathrm{C}$.

\subsection{Biotite-garnet thermometry}

The $\mathrm{Fe}-\mathrm{Mg}$ exchange biotite-garnet thermometer was given first by Ferry and Spear (1978), Spear (1993). The Fe-Mg exchange thermometer of Ferry and Spear (1978) is based upon the exchange reaction given by

$$
\begin{gathered}
\underset{\text { Almandine }}{\mathrm{Fe}_{3} \mathrm{Al}_{2} \mathrm{Si}_{3} \mathrm{O}_{12}}+\mathrm{KMg}_{3} \mathrm{AlSi}_{3} \mathrm{O}_{10}(\mathrm{OH})_{2}= \\
\underset{\text { Phlogopite }}{\mathrm{Mg}_{3} \mathrm{Al}_{2} \mathrm{Si}_{3} \mathrm{O}_{12}}+\mathrm{KFe}_{3} \mathrm{AlSi}_{3} \mathrm{O}_{10}(\mathrm{OH})_{2} \\
\quad \text { Annite }
\end{gathered}
$$

Temperature is calculated as

$$
T(\mathrm{~K})=\frac{2109}{\ln K_{d}-0.782}
$$

$K_{d}=$ distribution coefficient of equilibrium phases of $\mathrm{Fe}^{2+}-\mathrm{Mg}$ with garnet.

Subsequently, several formulations of the biotitegarnet geothermometer have been suggested to take into account non-ideality of mixing of components.

In the present study, biotite-II grains are seen in equilibrium with garnet grains in the sample. The biotite grains (Bt-II) also cross-cut the early hornblende-chlorite fabric. The analyses of Bt-II grains are given in supplementary file and the results of biotite-garnet geothermometry are given in table 3 on the basis of seven different formulations as indicated in table 3. All the geothermometers except for those of Bhattacharya et al. (1992) and Dasgupta et al. (1991) show fairly consistent results. The estimates obtained from Bhattacharya et al. (1992) and Dasgupta et al. (1991) are not considered further in the present study.

The temperature estimated from core-core pairs of analysis in the garnet and biotite grains show a range between 515 and $548^{\circ} \mathrm{C}$ with a mean value of 536C. Temperature estimates from pairs of points towards the rims of the grains show values that range from 434 to $519^{\circ} \mathrm{C}$. The results show that the temperature estimates from core-core pairs are higher than that obtained from rim-rim pairs in all formulations of the garnet-biotite geothermometer. However, since the sample shows alteration due to subsequent hydrothermal events only the results from core-core pairs are retained for 
Table 3. Results of garnet-biotite geothermometry $\left({ }^{\circ} \mathrm{C}\right)$ of samples of garnetiferous amphibolite from the Hira-Buddini mine (4th level) calculated at 2.5 kbars (based on seven calibrations, computed at 2.5 kbars).

\begin{tabular}{lcccccccc}
\hline \multirow{2}{*}{$\begin{array}{l}\text { Garnet-Biotite } \\
\text { sample points }\end{array}$} & B92-HW & B92-GS & Dasg91 & FS78 & HS82 & PL83 & T76 & HL77 \\
\cline { 2 - 9 } $17 \mathrm{c}-21 \mathrm{c}$ & 502 & 445 & 326 & 515 & 547 & 546 & 542 & 534 \\
$26 \mathrm{c}-30 \mathrm{c}$ & 492 & 422 & 242 & 516 & 548 & 546 & 536 & 534 \\
$1 \mathrm{r}-9 \mathrm{r}$ & 482 & 435 & 293 & 470 & 497 & 519 & 499 & 500 \\
$26 \mathrm{r}-31 \mathrm{r}$ & 466 & 404 & 351 & 467 & 498 & 517 & 497 & 498 \\
$2 \mathrm{r}-9 \mathrm{r}$ & 475 & 440 & 268 & 434 & 467 & 496 & 470 & 474 \\
\hline
\end{tabular}

Note: B92 = Bhattacharya et al. (1992), Dasg91 = Dasgupta et al. (1991), FS78 = Ferry and Spear (1978), HS82 = Hodges and Spear (1982), PL83 = Perchuk and Lavrent'eva (1983), T76 = Thompson (1976), HL77 = Holdaway and Lee (1977); Abbreviations: $\mathrm{c}=$ core, $\mathrm{r}=\operatorname{rim}$ (biotite and garnet grain).

Table 4. Summary of garnet-hornblende and garnet-biotite geothermometry in garnetiferous amphibolite from the HiraBuddini mine (4th level).

\begin{tabular}{llll}
\hline Geothermometry & \multicolumn{1}{c}{ Method } & Rock types (sample no.) & $T^{\circ} \mathrm{C}($ Mean $)$ \\
\hline Grt-Hbl & Graham and Powell (1984) & \\
Grt-bt & Ferry and Spear (1978); Spear (1993) & Garnetiferous amphibolite (HBN-4) & 531 \\
\hline
\end{tabular}

Table 5. Estimated temperature using Ti-biotite thermometer in garnetiferous amphibolites from the 4 th level of Hira-Buddini mine.

\begin{tabular}{lccccc}
\hline $\begin{array}{c}\text { Analysis } \\
\text { pts. }\end{array}$ & $\mathrm{Mg} /(\mathrm{Mg}+\mathrm{Fe})$ & $\mathrm{Ti}$ & $\ln (\mathrm{Ti})$ & $\mathrm{Eq}$ & $T\left({ }^{\circ} \mathrm{C}\right)$ \\
\hline $8 / \mathrm{HBN}-4$ & 0.289 & 0.180 & -1.713 & 1431 & 520 \\
$9 / \mathrm{HBN}-4$ & 0.310 & 0.200 & -1.611 & 1671 & 547 \\
$10 / \mathrm{HBN}-4$ & 0.292 & 0.186 & -1.680 & 1505 & 529 \\
$21 / \mathrm{HBN}-4$ & 0.287 & 0.184 & -1.694 & 1469 & 524 \\
$22 / \mathrm{HBN}-4$ & 0.294 & 0.193 & -1.647 & 1577 & 537 \\
$32 / \mathrm{HBN}-4$ & 0.329 & 0.189 & -1.665 & 1576 & 537 \\
$57 / \mathrm{HBN}-4$ & 0.293 & 0.177 & -1.732 & 1392 & 515 \\
\hline
\end{tabular}

further interpretation. The mean temperature of garnet-hornblende and garnet-biotite is given in table 4.

\subsection{Ti-biotite thermometry}

For further corroboration of estimates of temperature obtained by the garnet-biotite geothermometry, Ti-content of the biotite (Bt-II) was used following the method proposed by Henry et al. (2005) for meta-aluminous pelites which coexist with independent Ti-phases. The rock under investigation is clearly not an amphibolite resulting from metamorphism of tholeiite. It is common to see bands of ilmenite in this rock. These bands represent compositional banding of the original metapelites. The bands of ilmenites are enclosed in later formed garnet indicating that these bands were formed early in the diagenetic and metamorphic history of the rock. These rocks are also different from amphibolites developed from the tholeiites in that they contain garnet grains whereas the metatholeiites are devoid of them. The geothermometer proposed by Henry et al. (2005) is based on Ti-saturation in biotite at $4-6$ kbars pressure and is given graphically by using the Ticontent in biotite vs. $\mathrm{Mg} / \mathrm{Mg}+\mathrm{Fe}$ content of biotite or by using the equation

$$
T\left({ }^{\circ} \mathrm{C}\right)=\left(\frac{\left[\ln (\mathrm{Ti})-a-c\left(\mathrm{X}_{\mathrm{Mg}}\right)\right]}{b}\right)^{0.333}
$$




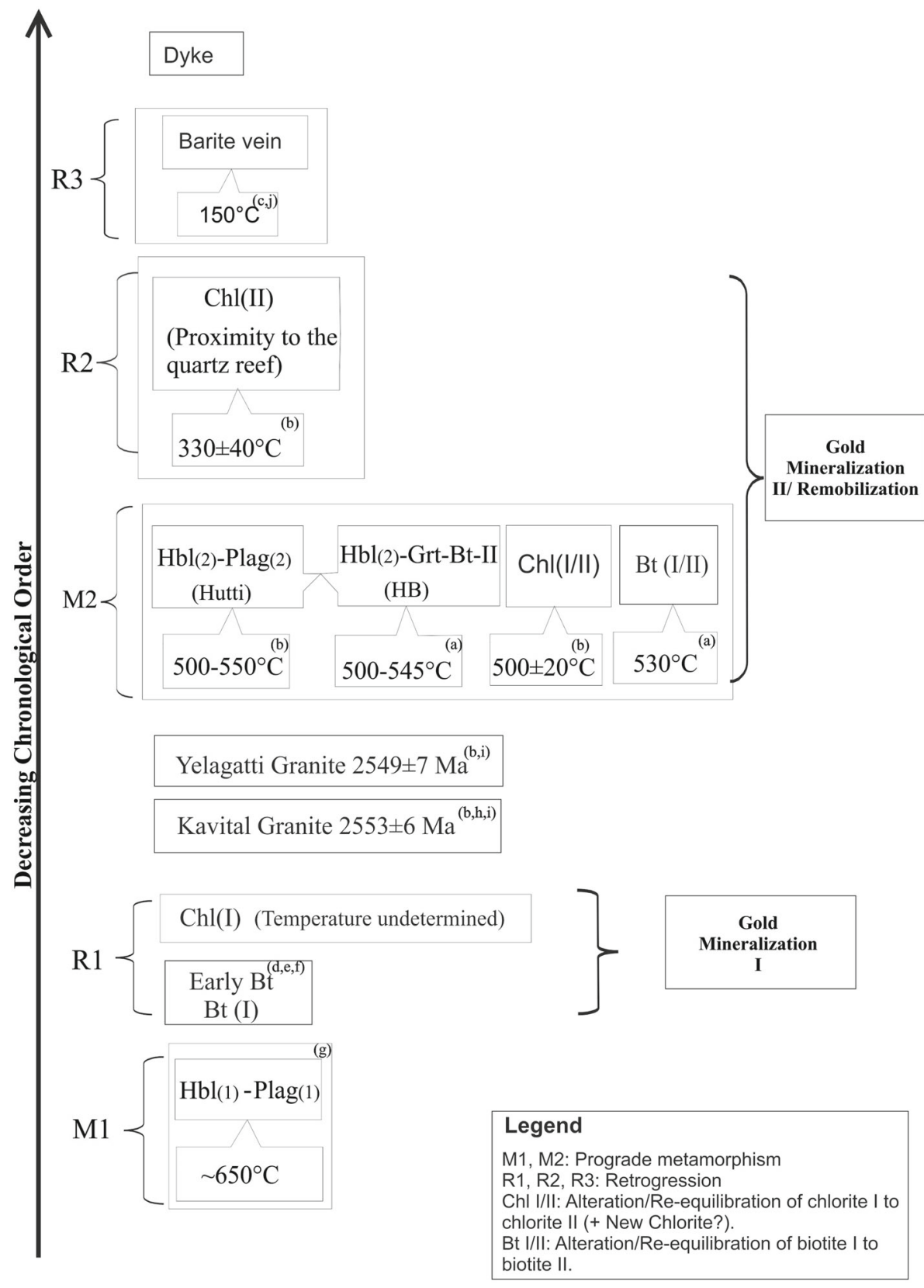

Figure 7. Schematic interpretation of the evolution of Hutti-Maski greenstone belt, Eastern Dharwar craton. The thermometry data in the Hutti schist belt from literature has been added. HB: Hira-Buddini. References: (a) Present study; (b) Badhe (2017); (c) Badhe and Pandalai (2015); (d) Roy (1979, 1991); (e) Naganna (1987); (f) Hazarika et al. (2017); (g) Mishra and Pal (2008); (h) Kolb et al. (2005); (i) Anand and Balakrishnan (2010); (j) Nevin and Pandalai (2010).

where $T$ is temperature in ${ }^{\circ} \mathrm{C}$, $\mathrm{Ti}$ is the apfu normalized to 22 oxygens, $\mathrm{X}_{\mathrm{Mg}}$ is $\mathrm{Mg} /(\mathrm{Mg}+\mathrm{Fe})$, and $a=-2.3594, b=4.6482 e-9$ and $c=-1.7283$.

The influence of pressure on the temperature determined is to cause higher $\mathrm{Ti}$ saturation at lower pressure and lead to overestimation of temperature (Henry et al. 2005). The pressure is not specifically determined here but estimates from the literature on the Hutti-Maski greenstone belt for the M2 event are lower than the minimum 4 kbars pressure given by Henry et al. (2005) for his calibration. The temperature obtained is given in table 5 . The estimated temperature is between 515 and $547^{\circ} \mathrm{C}$ with a mean of $530^{\circ} \mathrm{C}$ and is consistent with estimates obtained from other geothermometers.

\section{Discussion and conclusions}

A schematic summary of the evolution of the HuttiMaski greenstone belt constructed on the basis 
of previous studies on the Hutti-Maski greenstone belt available in the literature as well as the results of the present study in figure 7 .

The garnetiferous biotite schist at Hira-Buddini is compositionally distinct in comparison to other amphibole-bearing metabasalts of the Hutti-Maski greenstone belt. At Hira-Buddini, petrography shows that the garnet porphyroblasts, the second generation hornblende (Hbl-II) and biotite (Bt-II) have grown over an earlier fabric with hornblende (Hbl-I) which had retrogressed and altered to an early chlorite (Chl-I). The parallelism of the S1 schistosity defined by the early hornblende (HblI), plagioclase (Plag-I) and the ilmenite bands indicate that they are the products of the first (M1) phase of metamorphism. The S1 foliation is parallel to the mylonitic foliation that has developed along the ENE-WSW trending shear zone at the contact of the felsic and mafic volcanic rocks. Gold mineralization occurs in the narrow zone of shearing along the contact of the felsic and mafic volcanic rocks. The early mineralization resulted in hydrothermal alteration and retrogression in narrow regions around hydrothermal pathways.

The parallelism of the shear with S1 foliation and the parallelism of early alteration as chlorite with S1 foliation indicate that the early alteration may have occurred at the late phase of D1 deformation (as described by Roy 1991). In the Hira-Buddini deposit gold mineralization is primarily controlled by the narrow mylonitized zone and is therefore inferred to result from early hydrothermal ingress during the late stages of D1 deformation. Geothermometric estimates of the early M1 event are not possible from the garnetiferous schist because of alteration of the hornblende (Hbl-I) and plagioclase (Plag-I) assemblage to chlorite (Chl-I) and because of subsequent hydrothermal and metamorphic effects.

Second generation hornblende (Hbl-II) and biotite (Bt-II) occur at high angles to the early $\mathrm{S} 1$ fabric and is parallel to $\mathrm{S} 2$ foliation. The S2 foliation follows a $\mathrm{N} 5^{\circ} \mathrm{W}$ trend at Hira-Buddini and is parallel to the subvertical axial planes of F2 folds. Hbl-II-garnet and garnet-Bt-II geothermometry give the temperature of 545 and $513^{\circ} \mathrm{C}$, respectively and thereby falls in the range of $530 \pm 15^{\circ} \mathrm{C}$. Geothermometry based on Ti-in biotite (Bt-II) from this same rock also gives a temperature range of $530 \pm 20^{\circ} \mathrm{C}$. This temperature estimate relates to the D2 stage of deformation and the M2 stage of metamorphism. It is inferred here that the M2 stage of metamorphism is related to the emplacement of rocks of granodioritic composition along the south-eastern and northern boundaries of the Hutti schist belt that correlates with the second stage of TTG emplacement in the EDC $(\sim 2.58-2.54 \mathrm{Ga})$ as proposed by Jayananda et al. (2013).

The alteration of garnet porphyroblasts and the formation of pseudomorphs of garnet composed of albite-epidote-chlorite II-calcite-zoisite assemblage indicate that the M2 stage of metamorphism was followed by a stage of low-temperature hydrothermal alteration around regions of hydrothermal ingress. From the present study, it is not possible to infer whether the second low-temperature albiteepidote-chlorite II-calcite hydrothermal phase is related to hydrothermal fluids of a late D2 phase or the later D3 phase.

The following conclusions are drawn from this study:

i) An early phase of prograde metamorphism led to the development of hornblende and plagioclase and bands of ilmenite that defines the S1 schistosity in the rock. The early hornblende (Hbl-I) was altered to biotite (Bt-I) and chlorite (Chl-I) in an early stage of hydrothermal alteration. The S1 schistosity is parallel to the mylonitic zones developed along shears at the contact of the felsic and mafic volcanic rock at Hira-Buddini that hosts the gold mineralization.

ii) The second generation hornblende (Hbl-II) and biotite (Bt-II) grains are parallel to S2 foliation marked by fractures and veinlets parallel to the axial planes of $\mathrm{F} 2$ folds.

iii) Garnet-hornblende and garnet-biotite geothermometry of the garnetiferous amphibolites at Hira-Buddini give (mean) estimates of 531 and $536^{\circ} \mathrm{C}$, respectively. Estimates of temperature from $\mathrm{Ti}$ in biotite give a mean value of $530^{\circ} \mathrm{C}$ and clearly fall within the temperature range of the retrogressive phase inferred from hornblende-plagioclase geothermometry of Hutti amphibolites (Kolb et al. 2005; Mishra and Pal 2008).

iv) A late stage of hydrothermal alteration led to alteration of garnets along zones of fluid access to an assemblage consisting of albitechlorite II-epidote and zoisite. The two stages of fluid ingress and alteration are consistent with the observations of Hazarika et al. (2016), 
Mishra and Pal (2008), Krienitz et al. (2008) and Rogers et al. (2013).

v) Primary gold mineralization at Hira-Buddini is inferred to have caused by the early stage of hydrothermal fluids after peak D1 phase of deformation and metamorphism (Roy 1979, 1991; Vasudev and Chadwick 2008; Nevin 2012). The phase of development of secondgeneration hornblende (Hbl-II), garnet porphyroblasts and biotite (Bt-II) is inferred to be related to emplacement of rocks of granodioritic composition along the south-eastern and northern boundary of the Hutti schist belt and correlates with the second phase of granodiorite and TTG emplacement in the EDC as inferred by Jayananda et al. (2013). This phase may be correlated with the D2 phase of deformation of Roy $(1979,1991)$.

vi) The present work clearly shows that the late hydrothermal phase followed the second metamorphic phase and may have occurred during the late D2 phase or later during the D3 phase of deformation.

\section{Acknowledgements}

The authors acknowledge with gratitude infrastructure facilities provided by the Indian Institute of Technology Bombay. Authors are indebted to the Hutti Gold Mines Co. Ltd., and Dr P Sangurmath (General Manager, Coordination) for providing logistic support to Dr KB for carrying out the work. The authors thank Prof. S C Patel for providing the analytical assistance at the DST-IITB National facility for EPMA in Department of Earth Sciences, Indian Institute of Technology Bombay.

\section{References}

Anand R and Balakrishnan S $2010 \mathrm{~Pb}, \mathrm{Sr}$ and Nd isotope systematics of metavolcanic rocks of the Hutti greenstone belt, Eastern Dharwar Craton: Constraints on age, duration of volcanism and evolution of mantle sources during Late Archean; J. Asian Earth Sci. 39 1-11.

Anantha Iyer G V and Vasudev V N 1979 Geochemistry of the Archean metavolcanic rocks of the Kolar and Hutti gold fields; J. Geol. Soc. India 20 419-432.

Badhe K V and Pandalai H S 2015 Investigation of possible re-equilibration of aqueous fluid inclusions in barite and calcite from the Hutti gold deposit, Karnataka, India; Acta Geologica Sinica, Willey Online Library 85(3) 715725 .

Badhe K V 2017 Ore petrology, alteration assemblages and 40Ar-39Ar geochronology of Hutti gold deposit, Raichur district, Karnataka, India, Unpubl. PhD thesis, Indian Institute of Technology Bombay, 230p.

Bhattacharya A, Mohanty L, Maji A, Sen S K and Raith M 1992 Non-ideal mixing in the phlogopite-annite binary: Constraints from experimental data on $\mathrm{Mg}-\mathrm{Fe}$ partitioning and a reformulation of the biotite-garnet geothermometer; Contrib. Mineral. Petrol. 111(1) 8793.

Curtis L C and Radhakrishna B P 1995 Hutti Gold Mine into the 21st Century; Geological Society of India, Bangalore, $179 \mathrm{p}$.

Dasgupta S, Sengupta P, Guha D and Fukuoka M 1991 A refined garnet-biotite $\mathrm{Fe}-\mathrm{Mg}$ exchange geothermometer and its application in amphibolites and granulites; Contrib. Mineral. Petrol. 109(1) 130-137.

Deer W A, Howie R A and Zussman J 1992 An Introduction to the Rock-Forming Minerals; 2nd edn, Longman Group Limited, London, UK.

Droop G T R 1987 A general equation for estimating $\mathrm{Fe}^{3+}$ concentrations in ferromagnesian silicates and oxides from microprobe analyses, using stoichiometric criteria; Mineral. Mag. 51(361) 431-435.

Ellis D J and Green D H 1979 An experimental study of the effect of $\mathrm{Ca}$ upon garnet-clinopyroxene $\mathrm{Fe}-\mathrm{Mg}$ exchange equilibria; Contrib. Mineral. Petrol. 71 13-22.

Ferry J T and Spear F S 1978 Experimental calibration of the partitioning of $\mathrm{Fe}$ and $\mathrm{Mg}$ between biotite and garnet; Contrib. Mineral. Petrol. 66(2) 113-117.

Giritharan T S and Rajamani V 1998 Geochemistry of the metavolcanics of the Hutti-Maski Schist Belt, South India: Implications to gold metallogeny in the eastern Dharwar Craton; J. Geol. Soc. India 52 583594.

Graham C M and Powell R 1984 A garnet-hornblende geothermometer: Calibration, testing, and application to the Pelona Schist, Southern California; J. Metamophr. Geol. 2(1) 13-31.

Hazarika P, Pruseth K L and Mishra B 2015 Neoarchean greenstone metamorphism in the Eastern Dharwar Craton, India: Constraints from monazite $\mathrm{U}-\mathrm{Th}-\mathrm{Pb}$ total ages and PT pseudosection calculations; J. Geol. 123(5) 429-461.

Hazarika P, Mishra B and Pruseth K L 2016 Scheelite, apatite, calcite and tourmaline compositions from the late Archean Hutti orogenic gold deposit: Implications for analogous two stage ore fluids; Ore Geol. Rev. 72 9891003 .

Hazarika P, Mishra B and Pruseth K L 2017 Traceelement geochemistry of pyrite and arsenopyrite: Ore genetic implications for late Archean orogenic gold deposits in Southern India; Miner. Magazine 81 661678.

Henry D J, Guidotti C V and Thomson J A 2005 The Ti-saturation surface for low-to-medium pressure metapelitic biotites: Implications for geothermometry and Ti-substitution mechanisms; Am. Mineral. 90(2-3) 316-328.

Hodges K V and Spear F S 1982 Geothermometry, geobarometry and the $\mathrm{Al}_{2} \mathrm{SiO}_{5}$ triple point at Mt. Moosilauke, New Hampshire; Am. Mineral. 67 1118-1134.

Holdaway M J and Lee S M 1977 Fe-Mg cordierite stability in high grade pelitic rocks based on experimental, 
theoretical and natural observations; Contrib. Mineral. Petrol. 63 175-198.

Jayananda M, Peucat J J, Chardon D, Rao B K, Fanning C M and Corfu F 2013 Neoarchean greenstone volcanism and continental growth, Dharwar craton, southern India: Constraints from SIMS U-Pb zircon geochronology and Nd isotopes; Precamb. Res. 227 55-76.

Kolb J, Rogers A and Meyer F M 2005 Relative timing of deformation and two-stage gold mineralization at Hutti mine, Dharwar Craton, India; Mineral. Deposita 40156 174 .

Krienitz M S, Trumbull R B, Hellmann A, Kolb J, Meyer F M and Wiedenbeck M 2008 Hydrothermal gold mineralization at the Hira Buddini gold mine, India: Constraints on fluid evolution and fluid sources from boron isotopic compositions of tourmaline; Mineral. Deposita 43(4) 421434.

Leake B E, Woolet A R, Arps C E S, Birch W D, Gilbert M C, Grice J D, Hawthorne F C, Kato A, Kisc H J and Krivovichev et al. 1997 Nomenclature of Amphiboles: Report of the subcommittee on amphiboles of the International Mineralogical Association, commission on new minerals and mineral names; Canadian Mineral. 35(1) 219-246.

Mallik R K 2011 Ore petrological studies on gold mineralization at Hira-Buddini gold deposit, Hutti, Raichur district, Karnataka, India; MTech dissertation, Indian Institute of Technology Bombay, 150p.

Manikyamba C, Kerrich R, Khanna T C, Satyanarayanan M and Krishna A K 2009 Enriched and depleted arc basalts, with $\mathrm{Mg}$-andesites and adakites: A potential paired arc-back-arc of the $2.6 \mathrm{Ga}$ Hutti greenstone terrane, India; Geochim. Cosmochim. Acta 73(6) 17111736 .

Mishra B and Pal N 2008 Metamorphism, fluid flux, and fluid evolution relative to gold mineralization in the Hutti-Maski greenstone belt, Eastern Dharwar craton, India; Econ. Geol. 103(4) 801-827.

Naganna C 1987 Gold mineralization in the Hutti mining area, Karnataka, India; Econ. Geol. 82 2008-2016.

Nevin C G and Pandalai H S 2010 Fluid inclusion studies on barite from Hutti Gold Mines, Karnataka, India: inferences on late-stage hydrothermal fluid; Curr. Sci. 98(7) 955-962.

Nevin C G, Malli V M and Pandalai H S 2010 Modeling of Hutti gold deposits: Challenges and constraints. Gold metallogeny India and Beyond; Narosa Publishing House Pvt. Ltd., New Delhi, pp. 168-190.

Nevin C G 2012 Geochemistry and fluid characteristics of scheelite mineralization associated with gold in the Hutti deposit, Karnataka, India: Unpubl. PhD thesis, Indian Institute of Technology Bombay, 316p.

Pal N and Mishra B 2002 Alteration geochemistry and fluid inclusion characteristics of the greenstone-hosted gold deposit of Hutti, Eastern Dharwar Craton, India; Mineral. Deposita 37 722-736.

Pandalai H S, Jadhav G N, Mathew B, Panchapakesan V, Raju K K and Patil M L 2003 Dissolution channels in quartz and the role of pressure changes in gold and sulfide deposition in the Archean, greenstone-hosted, Hutti gold deposit, Karnataka, India; Mineral. Deposita 38(5) $597-624$
Pandalai H S, Jadhav G N, Mathew B, Panchapakesan V, Raju K K and Patil D J 2004 Reply to discussion on dissolution channels in quartz and the role of pressure changes in gold and sulphide deposition in the Archean, greenstone-hosted, Hutti gold deposit, Karnataka, India by Kolb J, Rogers A, Meyer FM; Mineral. Deposita 39 117-121.

Perchuk L L and Lavrent'eva I V 1983 Experimental investigation of exchange equilibria in the system cordieritegarnet-biotite; In: Kinetics and equilibrium in mineral reactions (ed.) Saxena S K, New York, Springer-Verlag, pp. 199-239.

Raju K K 1978 The geology and gold mineralisation at Hutti Gold Mines, Karnataka, India; PhD Thesis, Osmania University, Hyderabad, India.

Raju K K and Sharma J P 1991 Geology and gold mineralisation of the Hutti gold deposit, Karnataka, India; In: Brazil Gold '91 (ed.) Ladeira E E, Balkema, Rotterdam, pp. 469-476.

Ravna E K 2000 Distribution of $\mathrm{Fe}^{2+}$ and $\mathrm{Mg}$ between coexisting garnet and hornblende in synthetic and natural systems: an empirical calibration of the garnethornblende $\mathrm{Fe}-\mathrm{Mg}$ geothermometer; Lithos 53(3) 265277.

Rogers A J, Kolb J, Meyer F M and Armstrong R A 2007 Tectono-magmatic evolution of the Hutti-Maski Greenstone Belt, India: Constrained using geochemical and geochronological date; J. Asian Earth Sci. 31 5570 .

Rogers A, Kolb J, Meyer F M and Vennemann T 2013 Two stages of gold mineralization at Hutti Mine, India; Mineral. Deposita 48 99-114.

Roy A 1979 Polyphase folding and deformation in the HuttiMaski schist belt, Karnataka; J. Geol. Soc. India 20 598-607.

Roy A 1991 The geology of gold mineralization at Hutti in Hutti-Maski schist belt, Karnataka, India; Indian Minerals 45 229-250.

Roy A and Biswas S K 1982 A note on the 'volcanic conglomerate'/pyroclast horizon near Palkanmardi in the Hutti schist belt, Karnataka; J. Geol Soc. India 23506 510 .

Schumacher J C 1997 The estimation of ferric iron in electron microprobe analysis of amphiboles; Mineral. Mag. 61312 321.

Saha I and Venkatesh A S 2002 Invisible gold within sulfides from the Archean Hutti-Maski schist belt, Southern India; J. Asian Earth Sci. 20(5) 449-457.

Sahoo A K, Krishnamurthi R and Sangurmath P 2016 Auriferous lode of Hira-Buddini gold mine, Hutti-Maski schist belt, Dharwar craton: Mineralogy, alteration, types and mechanism of vein emplacement; J. Geol. Soc. India 88(6) 675-684.

Sangurmath P 2003 Detailed exploration for epigenetic gold deposits: A case history: Hira Buddini gold deposit, HuttiMaski schist belt, India; In: Mining in the 21st Century (eds) Ghosh A K and Bose I K, Oxford and IBM, New Delhi, pp. 315-329.

Sangurmath P 2005 Geology and Gold Mineralisation in Buddini Gold Deposit, Hutti-Maski Greenstone Belt, Karnataka; J. Geol. Soc. India 66(5) 552-560. 
Spear F S 1993 Metamorphic Phase Equilibria and Pressure-Temperature-Time Paths. Mineralogical Society of America Monographs; Mineralogical Society of America, Washington, D.C., 799p.

Srikantia S V 1995 Geology of the Hutti-Maski greenstone belt; In: Hutti Gold Mine into the 21st century (eds) Curtis L C, Radhakrishna B P, Geological Society of India, pp. 8-27.

Thompson A B 1976 Mineral reactions in pelitic rocks: II. Calculation of some P-T-X (Fe-Mg) phase relations; $A m$. J. Sci. 276 425-484.

Corresponding editor: N V Chalapathi RaO
Vasudev V N and Chadwick B 2008 Lithology and structure of the auriferous Hutti schist belt, northern Karnataka: Implications for Neoarchean oblique convergence in the Dharwar Craton, south India; J. Geol. Soc. India 71 239-256.

Vasudev V N, Chadwick B, Nutman A P and Hedge G V 2000 Rapid development of the Late Archaean Hutti schist belt, northern Karnataka: Implications of new field data and SCHRIMP U/Pb zircon ages; J. Geol. Soc. India 55 529-540. 